\title{
Surveillance \& Society Indigenous Surveillance Cinema: Indian
Education and the Truant On-Screen
} Article

\section{Joshua Miner}

University of Kansas, USA

j.d.miner@ku.edu

\begin{abstract}
Recent Indigenous boarding school movies have emphasized representations of surveillance together with the "living dead" as a central motif. After a brief review of surveillance in Indian education, this essay examines a cycle of films-The Only Good Indian (2009), Savage (2009), The Dead Can't Dance (2010), Rhymes for Young Ghouls (2013), and SNIP (2016) —wherein the practices and technologies of surveillance mediate a dynamic interplay between settler educational institutions and the Native runaway or truant. These films converge a popular undead motif with this longstanding genre figure of resistance by Native/First Nations children to settler systems of administration, drawing on its literary formation that extends back to the first Indigenous writing on federal Indian education. Within this larger field of what we may call Indigenous surveillance cinema, discourses of bureaucratic rationality frame the figure of the truant. These films articulate the ways that representational practices ranging from literacy to cinema uphold systems of identification by which administrative surveillance of Indigenous people continues. Cinematic representations of the supervision of Indigenous bodies recall settler-colonialism's mobilization of an array of early surveillance technologies for the assimilation of Native children. In this context, the watchful eye of the teacher-a proxy for administrative media - suggests a deeper embedding in settler systems of control. A visual poetics of truancy emerges in Indigenous surveillance cinema, as the truant figure operates dialectically with settler surveillance. The truant spatializes settler management and surveillance in her desire to escape cultural conversion at the hands of these proliferating technologies of representation.
\end{abstract}

\section{Introduction}

Lisa Jackson's musical short, Savage (2009), begins with a crosscut of a young Native girl taken from her home for boarding school in the 1950s while her mother sings a Cree lullaby in the family kitchen. When the girl arrives at school, she undergoes two transformations: (1) the school children avoid the teacher's watchful eye, obediently copying the English writing modeled on the chalkboard, and (2) as the teacher leaves the room, the rows of zombie children revive in a choreographed dance reminiscent of Michael Jackson's Thriller. Like the others, the Native girl has become both assimilated student and zombie.

Savage marked a remediation of the zombie trope into Indigenous cinema; earlier that year, The Only Good Indian (Willmot 2009) had been the first narrative feature to explore "undeath" and Indian education, as its runaway protagonist Nachwihiata becomes obsessed with Bram Stoker's Dracula and reads the novel aloud in voiceover to interpret settler officials as living dead. Other movies have continued to explore this theme: The Dead Can't Dance (Pocowatchit 2010), Rhymes for Young Ghouls (Barnaby 2013), and the experimental short SNIP (Calder 2016). ${ }^{1}$ They access the same history but intervene at different material and generic levels; through comedy, suspense, and stop-motion animation, these films synthesize education

1 The 2019 Indigenous zombie film Blood Quantum (directed by Jeff Barnaby) similarly explores the administration of Native blood and tribal membership.

Miner, Joshua. 2020. Indigenous Surveillance Cinema: Indian Education and the Truant On-Screen.

Surveillance \& Society 18(4): 467-480.

https://ojs.library.queensu.ca/index.php/surveillance-and-society/index | ISSN: 1477-7487

(c) The author(s), 2020 | Licensed to the Surveillance Studies Network under a Creative Commons

Attribution Non-Commercial No Derivatives license 
and the living dead. But this trope is more than good fun: here it transposes undeath to explore the assimilationist mission of Progressive Era settler-colonial education and its surveillance of Native people, whereby Native children become culturally white Americans. Captain Richard Pratt, who founded the first federal boarding school in Carlisle, Pennsylvania in 1879, alluded to this process in his famous phrase: "Save the Indian, kill the man." The literalization of Pratt's words as zombie or vampire expresses how the "whitening of [students'] skin reflects the 'whitening' of their self-understanding as cultural subjects" (Pearson and Knabe 2015: 4). Yet the specific methods for this transformation included surveillance practices and technologies honed in nineteenth-century US and Canada as a way to manage Indigenous people as their lands were stripped away. Inflected by settler-colonial values, surveillance helped manage the assimilation of Natives while they were "killed" and remade - rewritten and made legible - as EuroAmericans.

This essay explores cinematic depictions of settler surveillance practices and technologies in Indigenous movies that mediate boarding school narratives with motifs of living death. These practices mediate the dynamic interplay between settler-colonial educational institutions and a central figure in residential school stories - the Native runaway or truant. From The Only Good Indian to SNIP, these films merge the undead motif with this enduring figure of resistance by Native children to settler systems of discipline. A literary trope that extends back to the first Indigenous writing on federal Indian education, the truant spatializes the presence of settler management in her desire to escape cultural conversion into undeath. Collectively, these films interrogate an array of early surveillance technologies - from written and typed reports to magnifying glasses, photography, and other visual media - embedded in a system of regulating the bodies and behaviors of Native children. Lisa Cartwright likewise distinguishes cinema as "a cultural technology for the discipline and management of the human body" (qtd. in Zimmer 2011: 428); as a historical apparatus, these characteristics remediate from photography. The watchful eye of the teacher or the magnifying glassproxies for subsequent visual technologies-implies a deeper embedding in settler administration.

Native/First Nations boarding school films recall a history of rationalized management by settler-colonial agencies, where surveillance practices emerged and were refined in the US and Canada throughout the eighteenth and nineteenth centuries. The managerial directives of agencies like the Bureau of Indian Affairs (1824) and the Bureau of Ethnology (1879) relied on watching, recording data, and regulating Indigenous lives. Catherine Zimmer (2015: 5) notes that motion photography and cinema develop as "part of the biometric practices accumulating around the body" in the nineteenth century, although she fails to note their earlier use in the context of settler-colonialism. This essay posits a broader conception of "biometric practices" than acknowledged by Zimmer, integrated and mobilized by settler bureaucracies, which would prefigure the strain of early cinema that sought to record and catalog Native cultural practices for posterityexemplified by Thomas Edison's filmic experiments with Native dances in 1894. ${ }^{2}$ The first Indigenous literature to depict their antecedents, such as Francis LaFlesche's The Middle Five: Indian Schoolboys of the Omaha Tribe (1900), would portray the subtler practices of panoptical spatial organization, dress codes, and promotional photography that measured and advertised the progress of the "vanishing race" toward civilization.

These elements - settler colonialism, administrative regulation, and recording technologies that culminate historically in cinema - organize together in what we may call Indigenous surveillance cinema. Anishinaabe scholar Gerald Vizenor (2000: 25, 145) identifies ethnographic surveillance as a prime mediator between settler and Indigenous peoples that employs discovery and "cultural observance" through a variety of settler institutions. This dynamic has been visible across a range of films, from the harassed homeless Native man in the independent feature film Heater (1999, directed by Terrance Odette) to stop-motion music videos like Haida Raid 3: Save Our Waters (2014, directed by Amanda Strong), which highlighted video surveillance of Indigenous environmental activists. It has precipitated a long history of responses by Indigenous writers and filmmakers to "the continued vulnerability of individuals and communities to dominant ethnographic gazes [of] powerful [settler] institutions" (Eils 2017: 30). These diverse films fit into a larger genre of

${ }^{2}$ See Thomas Edison's Sioux Ghost Dance (1894) and Buffalo Dance (1894). 
surveillance cinema that Sébastien Lefait (2013: 5) describes simply as movies that thematize watching and warn against the perils of systematized observation. However, specific patterns surface across anti-colonial contexts, where surveillance has been critiqued as a discursive and aesthetic tool for objectifying dark bodies as reproductive, disciplined, and trophy objects (Shohat 2003; Amad 2013; Perera 2015). These are all active in Native/First Nations boarding school films, as the captured Indigenous body must be disciplined into assimilation so that it cannot culturally reproduce. Indigenous boarding school films emphasize both these historical dangers and lasting traumas of the widespread settler surveillance and assimilation program that was, until recently, federal Indian education. The zombie trope becomes useful in this context by evoking an atmosphere of suspicion and the overwhelming inevitability of settler control.

A few undead boarding school movies are especially illustrative: namely, the experimental short SNIP (Calder 2016) and the feature films The Only Good Indian (Willmot 2009) and Rhymes for Young Ghouls (Barnaby 2013). These movies frontload Native/First Nations people's unique relationship to surveillance, and they range from experimental short videos that see much of their circulation online to independent features that rely more on traditional exhibition venues. Across their differences, they resonate with each other by virtue of how they chart the disciplinary geography of settler institutional spaces as a means of escape, intervening in Thomas Levin's (2002) history of the rhetorical uses of surveillance. Levin cites Louis Lumière's 1895 factory film as key in the origination of cinematic surveillance, yet these experiments coincided with Edison's films that indicate a parallel surveillance history concerned with managing Native populations. ${ }^{3}$ Both frame their subjects according to their movement within systems of supervision present throughout surveillance films. The Native/First Nations movies above draw on this legacy while simultaneously introducing a dual rhetorical trope of escape — undead and truant.

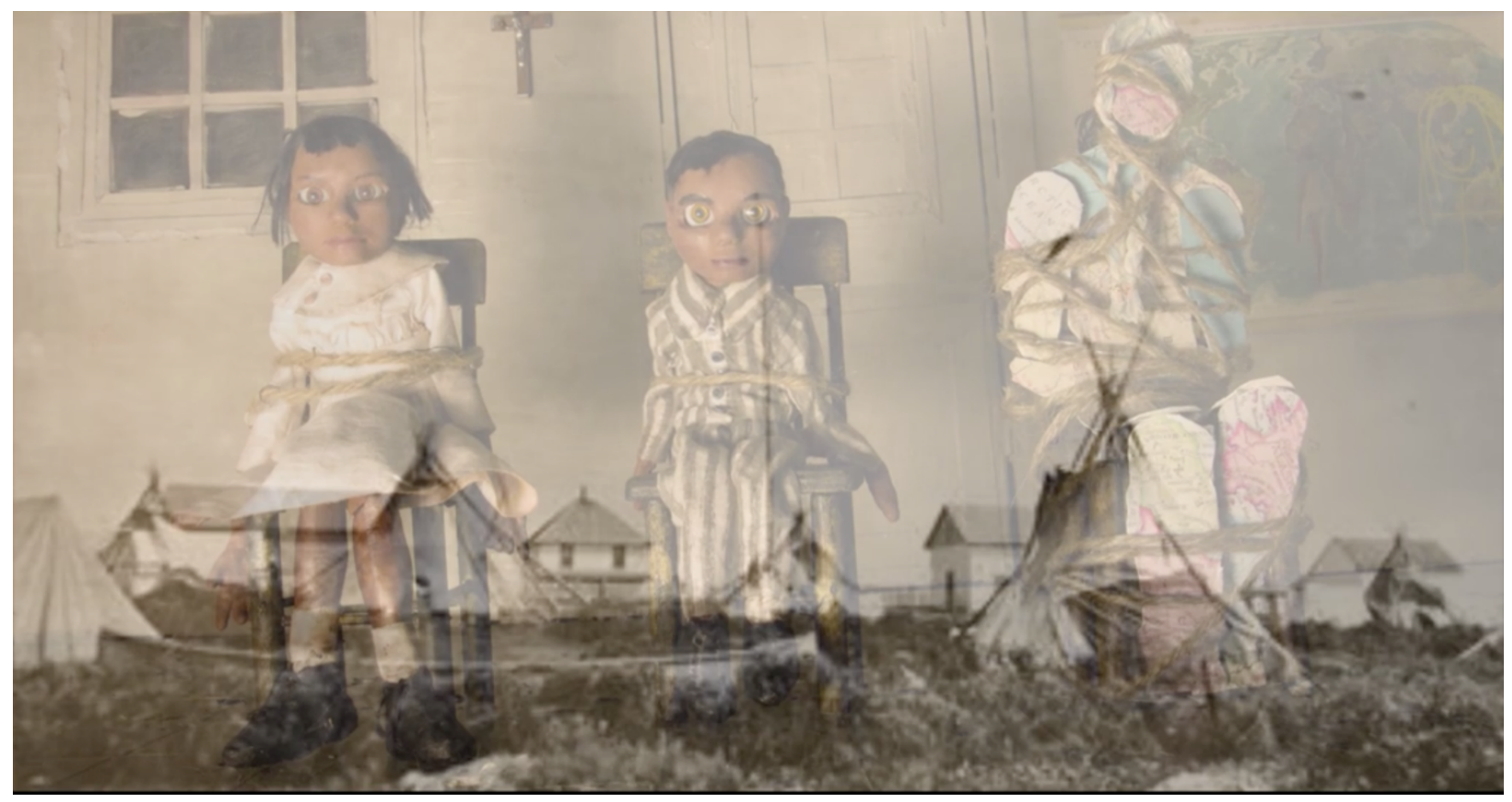

Figure 1: Niska, Charlie, and Gorden in SNIP (Calder 2016).

Following a recent history of Indigenous filmmaking, these movies have precipitated a rhetoric of sousveillance, which arises as Native individuals reappropriate expressive technologies and practices to observe settler institutions. Their narratives remain embedded in discourses of bureaucratic rationality, against which they assemble much of their meaning, where the Native runaway escapes control. They

${ }^{3}$ See Louis Lumiere's La Sortie de l'Usine Lumière à Lyon (1895). 
illustrate how the representational practices of settler-colonial education are functionally surveillant, as officials mobilize literacy, photography, and cinema to sustain an administrative system of categorization for the regulation of Indigenous children. Native characters use these same strategies to map settler spaces and routes of escape within the frame. By portraying imaginative expressions of self-determination through diverse production practices and genres, these movies produce a visual poetics of truancy in dialectic with settler surveillance. This works through technologies within and beyond the screen: the camera itself operates as a surrogate for an archaeology of media that joins the present moment with the late nineteenth century, when panoptic spyglasses, photography, and writing were predominant methods in a more embodied surveillance system.

\section{Technologies of Educational Surveillance On-Screen}

The early surveillance technologies depicted in Indigenous boarding school films mediate the relationship of Indigenous characters and settler institutions. As an experimental piece that places surveillance technology at the center of its narrative, Terril Calder's SNIP (2016) best visualizes this relationship, with symbolic, stylized stop-motion that sees human figures physically access historical spaces through media. The video features two present-day urban Anishinaabe people (as animated paper figures) who enter the past via the pages of several books - the Bible, a children's book, a history book, and an ethnographic report. The two urban Natives, Annie and Gorden, peer through the windows of a white boarding school in a historical photograph and then climb through to help Charlie and Niska, two children suffering in the Canadian residential school system. Annie and Gorden eventually free the two now-dead children and bring them into the present world, away from the school officials. Calder (Métis) literalizes the gaze of settler colonialism as her characters navigate printed and photographed representations of administrative spaces, and, at times, historical images are superimposed over the animated figures during disciplinary scenes when the children are subjected to a "reeducation program," forced to watch their captors" "version of history" (see Figure 1).

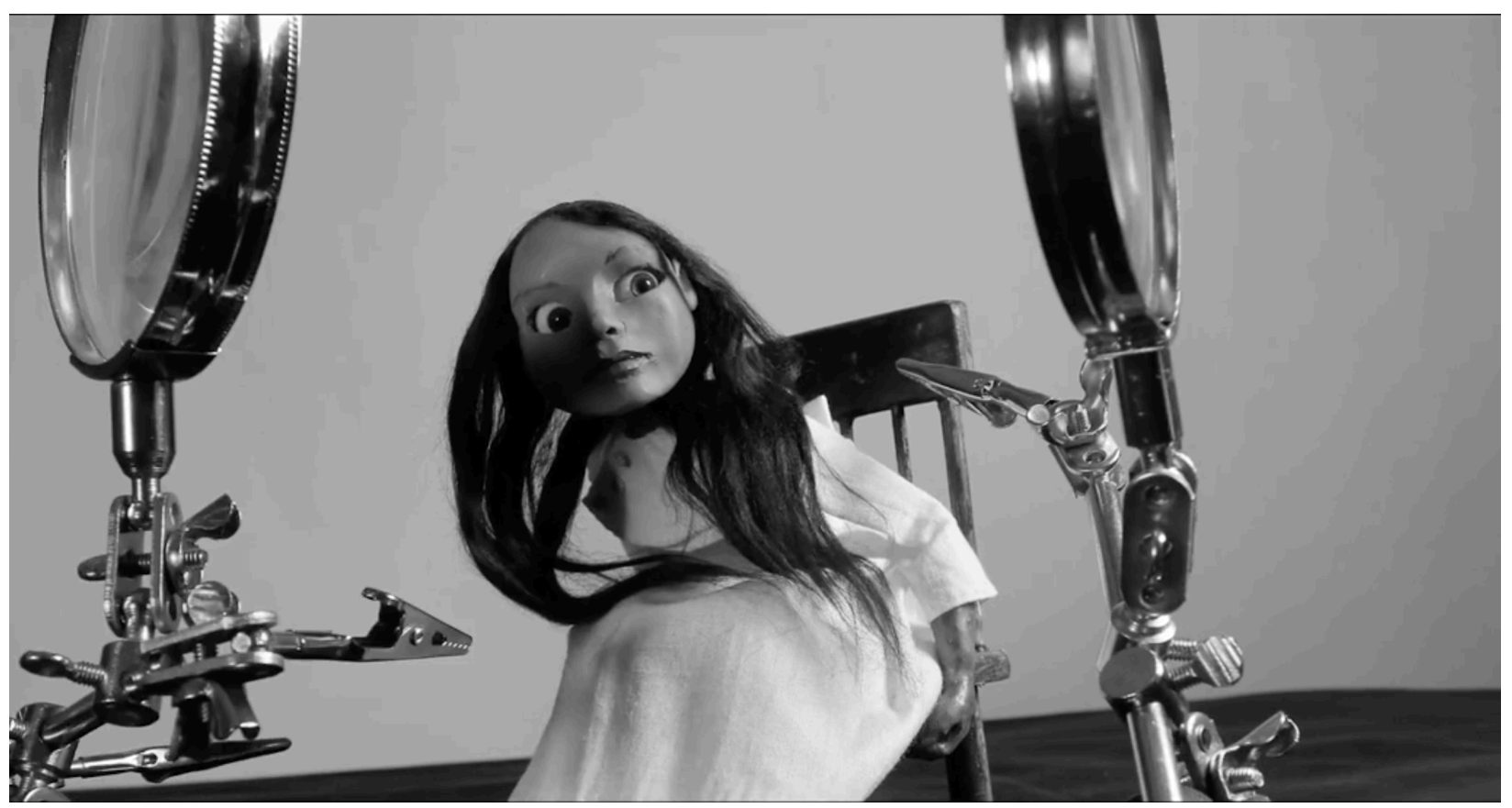

Figure 2: Boarding school officials in SNIP (Calder 2016).

Character design and mise-en-scène in SNIP emphasize this administrative mediation. The animator's painstaking manipulation of the settler figures, whose bodies are composed of surveillance media, especially 
places her in intimate contention with systems of colonization. Boarding school officials are signified by giant magnifying glasses with binder-clip hands as well as giant typewriters that observe the children (Figure 2 and Figure 3). Charlie and Niska are represented by realistic stop-motion puppets, Annie and Gorden by paper dolls cut from a map. The array of observation technologies remediated into the film operate symbolically to create an atmosphere of scrutiny; perhaps more importantly, they operate metonymically, signifying a much vaster surveillance apparatus. The figures evoke the historical surveillance of Native children that systematized a "federal mania to collect and store information" and produced reports that erased Indigenous cultures, an archival practice that has served as "the lifeblood of [settler] bureaucracy" (Lomawaima and McCarty 2006: 11). Mundane tools of oversight like roll books and records connote a rationalized, bureaucratic textuality that legitimized doctored photographic evidence for Indigenous erasure. This media assemblage operated from a perspective of scientific management, reflected in cinematic tropes depicting the settler supervision of Indigenous bodies.

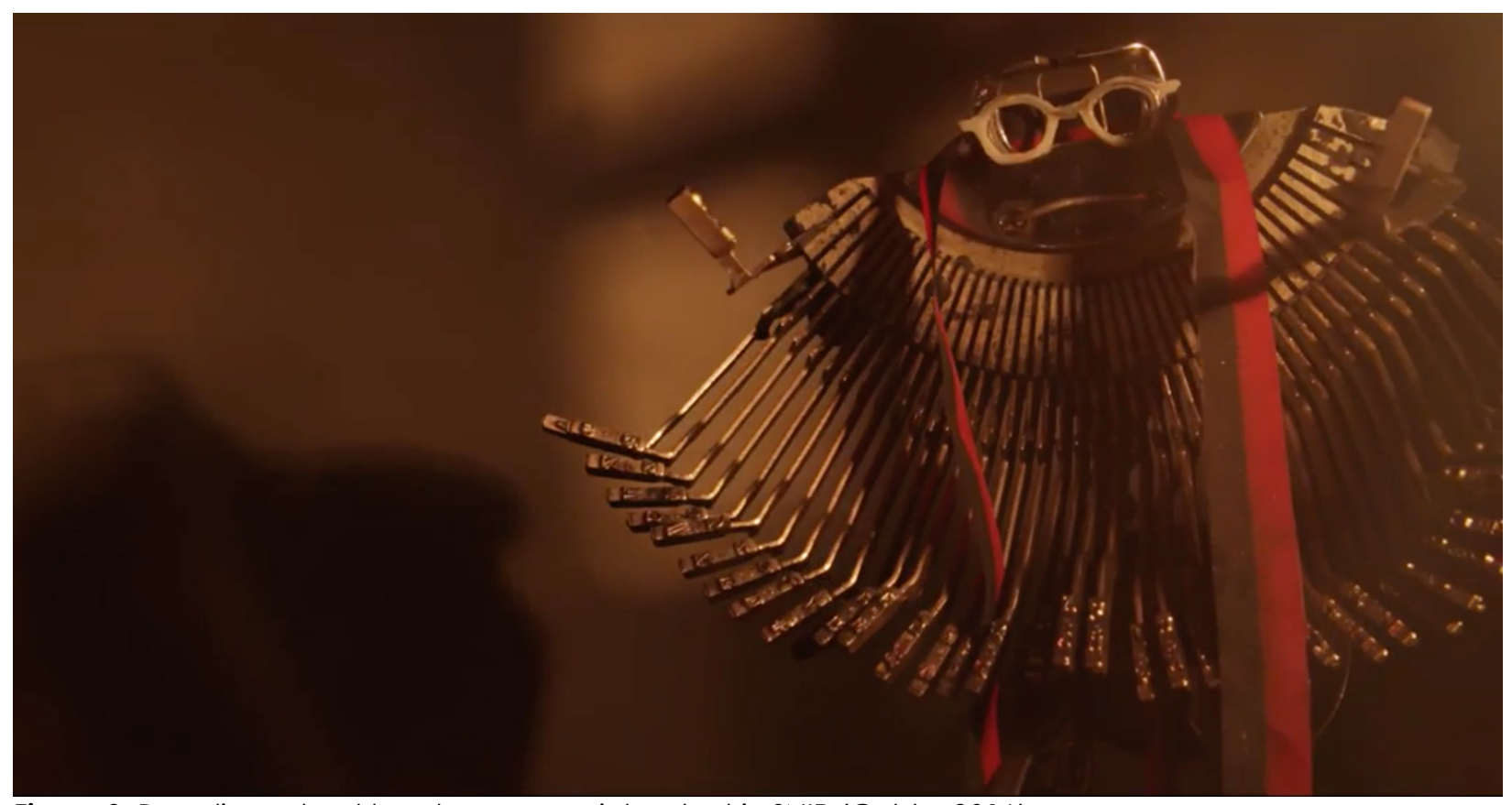

Figure 3: Boarding school teacher or superintendent in SNIP (Calder 2016).

In the late nineteenth century, reformers understood that the first technology of surveillance was space itself. Administrators actively constructed space to achieve complete control over bodies - visually, physically, and socially. Andrea Smith (2014: 211) describes settler educational spaces as "technologies of the body, [where] the body becomes the site of regulation such that power relations no longer seem to be that." Federal Indian boarding schools were built from the ground up as totalizing institutions and organized as prisons, with tall fences surrounding the campus, often with a central bandstand for observation. ${ }^{4}$ When Annie first peers into the boarding school photograph in SNIP, she sees a regimented classroom with desks oriented in columns and rows. A moment of resistance occurs: Niska, the captive girl, repeatedly rearranges the desks in a circle whenever the hovering magnifying glasses leave the room. This administrative presence connotes larger formations of settler-colonial oversight of Native communities. Jeffrey Monaghan (2013: 488) notes that the surveillance practices of Indian agents "not only aim to manage indigenous populations, but tend to

\footnotetext{
${ }^{4}$ Richard Pratt borrowed from his experience at Fort Marion for the organization of the Carlisle campus, which resembled a prison or a factory. It had a tall fence surrounding the campus, and plenty of methods for incarcerating disobedient students. At the center of all, "school officials placed a large, white bandstand where Pratt and his staff often observed the actions of students.... The all-seeing observer on the bandstand used administrative power to regulate the behavior of students at Carlisle" (Fear-Segal 2006: 99).
} 
produce racial subjectivities according to prefabricated typologies and normative demarcations held by settler societies." This mirrors our contemporary obsession with border security and the use of biometrics to enforce the integrity of borders and citizenship through racial types. Though with internal colonies such as reservations and residential schools, US agencies were fixated on keeping Indigenous people in, not keeping them out.

This environment created the necessary conditions for a "runaway spirit" that became rampant among Native students in the settler education model. ${ }^{5}$ Administrative surveillance provoked defiance by Native students in many forms: setting fire to school grounds, passively resisting curriculum, fighting with administrators and "clandestine acts of cultural preservation" like merely talking (Adams 1995: 233). Truancy compelled administrators to keep enrollment figures up in order to maintain the flow of per-capita agency funds (Lomawaima 1994: 120). Capturing truant students then became a practice of bureaucratic survival. This led to an escape-and-capture dynamic that created movement to and from administrative space, between assimilation and cultural integrity. This cycle marks Indigenous boarding school movies, working with operational surveillance as a dual narrative conceit. Mitigating this cycle required yet more pervasive surveillance of students' activities.

As photography and other visual media played such a central role in demonstrating administrative progress in converting "Indians" into "men," they feature heavily in Indigenous boarding school movies. While SNIP focuses its photographic images on the juxtaposition of Native/First Nations homes and boarding schools, The Only Good Indian places its young protagonist beneath oppressive promotional photographs, reminding him that his progress will constantly be measured. Michelle Raheja (Seneca) (2013: 282-283) construes this as a project of "intense visual documentation with its 'before and after' photographs designed to record and legitimate the children's movement from 'savage' to 'civilized' subject," which, over time, accumulated in a vast bureaucratic archive. These photographs presumed that identity was visible and measurable in the body, generating anxiety in captive Indigenous students but quelling progressive public anxieties about the morality of colonization. As manufactured evidence for the efficacy of Indian education, they illustrated "how dangerous cultural difference was being contained, made safe" (Lomawaima and McCarty 2006: 23). In turn, categorization was central to administrative surveillance of Indigenous children, coding and sorting racial identity in the production of a colonial form of modern subjectification. This early mode of surveillance became a tool of cultural conversion, as well as an early form of what Nikolas Rose (1999) calls the "securitization of identity" (Los 2006: 73; Lyon 2007: 130). Even nineteenth century Progressives viewed Indigeneity (let alone Indigenous nations) as an existential threat to the United States. Raheja (2013: 67) argues that before and after photographs express "a racial-optics system whereby Native Americans are policed through the dominant culture's ability to recognize them as Indigenous through their dress and physical and cultural separateness." Children were surrounded by images of separateness and transformation that represented the burden of proof laid upon them. As cultural difference was elided within the confines of federal Indian schools, Native children would not identify with either the promotional photographs or the progressive narrative that joined them.

For settler-colonial education, surveillance became a core function of educational media in order to reinforce difference. Media technologies project the resulting images of Native deficiency and disobedience onto Indigenous children exploited for a national narrative. This inscription of cultural tropes sets the preconditions for surveillance. It also elicits some of the most frightening scenes in Indigenous surveillance movies. In $S N I P$, young Niska and Charlie are both beaten repeatedly by the typewriter figure, who lashes the children to type "SAVAGE" and "BAD" over and over again on their clothes in red ink. This reflects how federal Indian education sought to transform the Indigenous population while still maintaining cultural and racial boundaries. Instead, boarding schools could neither control Native bodies nor their expressions of resistance. Students learned to coopt media technologies for their own expressions of identity, practicing

${ }^{5}$ In 1895, Colville Agency teacher L. W. Parker addressed a group of superintendents and instructors during the Indian Summer Institute in Tacoma, Washington. Reading from a paper titled "Discipline," Parker warned of a "runaway spirit" rampant among Native students (Office of Indian Affairs 1895: 69). 
a "covert literacy" of self-representation (Rockwell 2005: 9). Brenda Child (Ojibwe) (1998: 94) notes that "rebellion was a permanent feature of boarding school life, and runaways and stories of resistance figure prominently in the letters and reports" of boarding schools. Indigenous boarding school cinema continues this tradition: Niska and Charlie fight back against the surveilling administrators, perform improvised Native dances in the classroom, and finally escape from the record books that had trapped them, only to write their own stories. SNIP reflects Native boarding school students' discursive resistance, as a visual poetics of truancy disrupts the discourses and narratives of settler-colonial education.

Indigenous surveillance cinema exhibits distinct markers from mainstream surveillance cinema, particularly in how it mediates settler-Indigenous relations. Mainstream films focus on the socio-technical processes by which surveillance is situated, illustrating late-capitalist surveillance apparatuses like CCTV, datamining, and biometrics. Within this horizon of hypermediation, reality reaches the viewer through a "wall-to-wall... surveillance regime" of viewing technologies, what Garrett Stewart (2012: 5) calls a "technopticon." This is true of Indigenous boarding school movies, yet those set in the nineteenth century like The Only Good Indian focus on antecedent technologies that mediate and signify racial difference. Literacy and photography connote civilization such that Indigenous characters will always be excluded as objects, never subjects, of modernity. Contemporary surveillance does recall earlier forms of biometrics, in which bodies were tracked and managed and the data produced in this process were rationalized for the optimization of regulatory practices. Remarking on Christian Parenti's work, Zimmer (2015: 22) cites wanted posters as early surveillance media, noting that their defining feature is "the production of bodies as informationally and visually identifiable." Identification for capture was a characteristic of boarding school surveillance practices as well. However, a slippage in the subjective formations produced by settler before and after photographs emerges in how they categorically denigrate Indigenous individuals yet establish them as antecedents to their own micromanaged assimilation. The only thing left to do is escape.

\section{Truancy in Indigenous Surveillance Cinema}

Indigenous surveillance cinema emphasizes the ways that settler socio-technical systems delineate Native/First Nations people. It emerges from histories of documentary and ethnographic film, whose mode of observation "freezes its subjects" into a colonial story (Hearne 2006: 310). Its recursive nature lies not in repetitions of hypermediated viewing, recording, and reviewing, but in repetitions of administrative regulation. For this reason, Indigenous surveillance cinema reframes discourses of Indigenous visibility in the context of histories of objectified visibility. It is part of a larger trend of Indigenous filmmaking that has made an impact through its revision of boarding school history. Children in boarding school films like The Only Good Indian and Rhymes for Young Ghouls are imminently aware of being monitored, and their anxiety reflects Foucault's (1995: 176) recognition of the inextricable relationship between oversight, discipline, and education. Zimmer (2015: 13-14) argues that "the cinematic mediation of surveillance is part of a framework that organizes... subjective formations through [the] technological." Technologies matter: in this context, settler officials granted specific oversight over Native children embody a comprehensive machine of files, reports, requisition forms, and photographs that facilitate and legitimize their work. The dynamic of containment that results from this surveillance regime in turn manifests a set of oppositions that, over time, Native filmmakers have exploited in a realignment of administrative subjectivity. Two hallmark tropes signify an administrative presence: (1) the superintendent, embodiment and instrument of managerial literacy and power; and (2) the boarding school, site of confinement and conversion. Together, they produce a field of control that elicits a gesture toward escape. In the structure of a longer narrative, multiple cycles of escape and return can come to fruition.

Positioned against these forces of oversight, a third figure emerges: the Native truant, the unmanageable pupil and fugitive from regulation. The truant disrupts the web of pedagogical relations predicated on administrative practice, where the regimentation of settler education breaks down. She expresses differing relationships to different administrative faces: the textual (settler policy/documentation), the interpersonal (superintendents, agents, teachers), and the spatial (the boarding school itself). Her escape activates within each of these dimensions concurrently. The truant in turn produces the truant officer, sent to capture and 
return the runaway student. The truant officer figure is especially present in The Only Good Indian, starring Wes Studi and other Native actors, and Rhymes for Young Ghouls (2013), directed by Mi'kmaq filmmaker Jeff Barnaby, which has a tagline from distributor Monterey Media that reads, "Her only options are to run or fight... and Mi'gMaq don't run." While Rhymes for Young Ghouls centers on the Canadian boarding school experience, The Only Good Indian tells the story of a Kickapoo boy, Nachwihiata (Winter Fox Frank), who escapes from a Kansas training school only to be pursued separately by truant officer Finkle (T. Max Graham); infamous white "Indian fighter" and sheriff, Henry McCoy; and Sam Franklin (Wes Studi), a "civilized" Cherokee bounty hunter with unrealistic hopes of joining the Pinkerton detective agency. They form a complicated web of relations and catch-22s, where Franklin is both institutional captor and surveilled and escaped Native. Yet they all stand in relation to the administrative system. When meeting truant officer Finkle later in the film, Sam tells him: "Once they're all finally taken in, you're out of a job"signaling how settler-colonial education relies on a cycle of truancy for its own legitimacy. The three men's jurisdictions, authority, and aims often contradict each other.

In Indigenous surveillance cinema, truancy figures in relation to administrative media and disciplinary space. The Only Good Indian opens with young Nachwihiata playing stickball with his parents, who have been hiding him from mandated boarding school. Nachwihiata is quickly captured by white truant officers on horseback. The movie shifts to the boarding school, where the superintendent offers a welcome speech to a group of captured children who wear gendered Eurowestern clothes and nametags around their necks labeling their new colonial identities - the "men" or "women" that would be saved after the "Indian" inside had been killed. First, the superintendent describes a pervasive system of control: "This is not a prison. There are no walls, no fences - but there is a clock. The clock is here to provide order and discipline. The white man uses time to manage the world." Yet he reminds them of the physical risks involved and presumes their resistance, warning them that "taking leave of this institution is strictly forbidden. Should you wander astray, once you are returned, your transgression will be dealt with in a swift and decisive manner, with punishment meted out accordingly." As the core mechanism in the advancement of Native assimilation at the Kansas boarding school, the superintendent expresses control over the files of runaway students. He contends that the information contained within the files remains the sole property of the Office of Indian Affairs. This is an early step in the mediated alienation necessary for later forms of socio-technical surveillance systems.

Rhymes for Young Ghouls also uses truancy as its narrative impetus, situating it in a late-twentieth-century Canadian context where the truant is subject to a different system of surveillance by administrative officials. Set on the (fictional) Red Crow Indian Reservation in 1969, the film begins with a series of passages excerpted from Canada's Indian Act of 1876. The first explains that, by law, every physically able Indigenous child between the ages of five and sixteen must attend an Indian Residential School. The second juxtaposes compulsory education mandates with the mechanisms that keep this system in operation: "Her majesty's attendants, to be called truant officers, will take into custody a child whom they believe to be absent from school using as much force as the circumstance requires."

This foregrounds the role physical discipline plays in cycles of escape and capture in the film, as well as the way that disobedience - especially the kind that emancipates Native children-provides a pretext for violence. Unless, of course, one can afford the "truancy tax." The levy works as a rationalized, monetized exploitation of fugitive action, among the most desperate of actions taken by students. In the next frame, the following passage in the Indian Act displays: "A person caring for an Indian child who fails to cause such a child to attend school shall immediately be imprisoned, and such person arrested without warrant and said child conveyed to school by the truant officer."

At the mandate of the agency, the truant officer positions himself counter to these trajectories of escape. This figure becomes important in stories where alternating interpositions generate a perpetually contested representational site. In the film, Indian Agent Popper (Mark Antony Krupa) commodifies Indigenous escape by looking the other way for an ample fee, exempting those able to pay from returning to school. The teenage protagonist and truant paying the Indian tax, Aila (Devery Jacobs), manages to earn enough 
money selling cheap designer drugs via a weed-growing operation with her uncle to keep her and her friends out of St. Dymphna's residential school (coincidentally named for the Irish Catholic saint of runaways).

The recurring presence of the Indian Agent and his thugs watching over Aila and her friends establishes a foil for practices of individual expression aimed at taking hold of media technologies and confronting settler institutions. In The Only Good Indian, Nachwihiata's self-made literacy, reading, and descriptions of his captors perform this function. Rhymes for Young Ghouls instead articulates visual sovereignty through defiant art practices. During a party scene, Aila wears a gas mask that the audience will discover belonged to her dead mother, a visual artist who would sketch and spray paint political art while wearing the mask and who taught Aila the valuable rhetorical potential of protest art. The art that Aila's mother produces in a flashback in the film functions as a proxy for the film itself, a rhetorical statement against surveillance. Having inherited her mother's talent, Aila now wears the mask to protect herself from smoke as she spends nights rolling and dipping specialty marijuana cigarettes for clients. This doubles as an act of tactical selfrepresentation. Noting their diverse strategies for coping with the strictures of administrative power, Aila looks around the party and quips, "This is what brings my people together: the art of forgetfulness." Druginduced emancipation from memory, poverty, trauma, and settler authority - though harmful - echoes the young characters' truancy and the mindlessness of zombies, but it is only a passage to Aila's growth within the film. Across this section of the movie, Aila believes she sees zombie versions of her mother and the young boy killed in the first scene, when she was a child.

The way these films handle spatial shifts according to surveillance technology is also indicative of boarding school narratives. During the story's climax, a group of former and current escaped students led by Aila breaks into the boarding school at night to play a prank. Not only are they dressed and painted like the dead, in Halloween costumes, but the abundance of imagery of dead children signal their presence as living dead, returning to haunt the institutional spaces that had once contained and disciplined them. The break-in signals a first step toward a determined response against the residential school, but it will require confronting and then adopting undeath as a strategy of resistance.

\section{Watching the Undead}

Pratt's axiom "Kill the Indian, save the man" pervaded the assimilationist rhetoric of residential schools, but his is not the only expression from the period that evokes images of living death. The title The Only Good Indian recalls "The only good Indian is a dead Indian," a phrase attributed to General Philip Sheridan, another infamous "Indian fighter." Like boarding school photographs and Edison's films, this language serves as an ethnographic prophecy for authorizing colonial policies of Indigenous erasure. Vizenor (2000: 159) sees an irony in the before and after photographs within this broader discourse, "because the representation of bodies as cultural evidence" precipitates the "death of the other, death by continuous photographic exposure." Layers of technical mediation in these stories - via photography and cinema, which developed alongside state ethnographic projects for documenting the "vanishing Indian" — articulate a living death that mobilizes more than zombies on screen. The motif of living death at first signifies representational death, but, as an aesthetic strategy, it deconstructs the categories and discourses of ethnographic supervision.

Indigenous boarding school movies employ undead imagery in an exploration of Native truancy. It begins with how they highlight the mortality rates that schools often faced. The Only Good Indian and Rhymes for Young Ghouls feature cemeteries and burial grounds as thresholds between the living, the dead, and the living dead. A conceptual paradox emerges as truants become or come into contact with zombies and vampires. These undead figures transgress several inviolable binaries - life and death, civilized and savage, and so on - that allow them to disrupt the logic of settler surveillance. After being captured by white truant officers in The Only Good Indian, Nachwihiata finds himself on a train to the boarding school. In voiceover he reads from Bram Stoker's Dracula: "Chapter one:... For the dead travel fast." Nachwihiata feels drawn to Dracula above other books at the school, situating the movie's narrative in a Eurowestern tradition of supernatural tales of monstrous men on the edge of human identity. When the children arrive at the school, the superintendent explains the process of cultural, psychological, and social conversion and the camera 
cuts away so he can be heard over scenes of Native children having their hair cut and being taught English. Within this montage, Nachwihiata receives his colonial name, "Charlie," and has his photograph takenbut the school employees can't get a clear shot, and Nachwihiata's headshots show only a blurred face. As a character, Nachwihiata constantly plays on the motif of living death: when he tells his Kickapoo friend of his plan to run away, Nachwihiata says, "I would rather die... than stay here"; the other boy responds, "Don't let them bring you back," a play on words that evokes a connection between truancy, capture, and undeath. When Nachwihiata announces his resolve to escape, the other boy hands him a crude wooden stake he has carved.

The Only Good Indian mobilizes undeath as a multifaceted critique of settler-colonialism. Nachwihiata learns to read on the run, after stealing a copy of Dracula when he escapes, and his reading throughout the film elicits contrary conceptualizations. The language remains ambiguous as white characters are described as undead. The truant officer, Finkle, and ex-"Indian fighter" Sherrif McCoy are both associated with Dracula. Nachwihiata reads a description of the vampire with the movie's first images of McCoy: "His face was deathly pale, and the lines of it were hard, like drawn wires. His eyes were positively blazing." Nachwihiata then turns to a description of the way settler violence propagates: "They cannot die, but must go on age after age adding new victims and multiplying the evils of the world. For all that die from the preying of the Undead become themselves Undead, and prey on their kind. And so the circle goes on ever widening, like as the ripples from a stone thrown in the water." Through the novel, Nachwihiata critiques the expansionist nature of settler-colonialism. The Only Good Indian may be read as a western, given its form and historical content, but the dynamic between McCoy and Cherokee bounty hunter Sam Franklin is filtered through gothic horror as Nachwihiata's narration about living death resituates our classic reading of cowboy and Indian.

The Only Good Indian mediates colonial identity through technology. Cherokee bounty hunter (and former scout for the US military) Sam Franklin represents a shifting but sincere capitulation to Euro-American assimilation. He tells Nachwihiata that "Sam Franklin is going to be the best white man he can be. I'm going to out-'white man' the goddamn white man." To actualize this, he gives up his former name, Black Fox, and carries an automatic pistol, wears a pilot's helmet and goggles, and rides around on an early gas-powered bike rather than a horse. The use of this technology marks Sam, as he finds himself straddling several ethnoracial borders. Sam tells Nachwihiata, "Problem is, Injuns don't use machines" and shows him a catalog "full of everything that the white man manufactures." Sam's act emphasizes technology and media as the primary mediator for conversion into whiteness. This occurs in broader terms, where several of the film's characters move in and out of truant officer subjectivity. Officer Finkle serves as the first villain: we see him eclipsed near the midpoint of the film, when he is shot and killed by Sheriff McCoy-Black Fox's former nemesis during the Indian Wars - when Finkle won't give up two abducted children as McCoy orders him to. Both Sam Franklin and Henry McCoy then continue to pursue Nachwihiata and other children across the Kansas landscape, complicating the clean racial lines assumed in many Native boarding school stories. Technology mediates the passage into whiteness and undeath offered to Native characters in these movies.

Rhymes for Young Ghouls features several undead tropes within its story of female truant Aila. As both a runaway and a facilitator for others' escape, teen Aila is shown to strike deals with educational bureaucrats, who feed on her and her friends via the truancy tax, just like a vampire or a zombie. And much like the contemporary zombie figure, the evil ghoul was believed to steal human corpses from graves and eat their flesh. ${ }^{6}$ The film begins ten years before the main narrative, with Aila's uncle, Burner (Brandon Oakes), drunkenly talking to young Aila and Tyler (Louis Beauvais) as they look at some of her mother's drawings (including one of a zombie):

${ }^{6}$ In this case, the creature appears in the title: "ghoul" derives from an old Arabic word, ghūl, meaning "to seize" (Oxford English Dictionary n.d.). 
BURNER: Ever seen the mill up close? They cook Indian kids up there for that zombie priest.

TYLER: What's a zombie?

BURNER: Jesus Christ, Tyler, don't they teach you anything up at that school? Zombies are dead people who come back to life to eat brains. Dumb brains, especially. Normally zombies will eat anyone. But these religified zombies... Why do you think so many kids go missing at St. D's?

AILA: I have something that will protect you.

She hands Tyler a picture her mother drew for her: a female Native warrior who "likes to fight dead people," like the zombie drawing they previously looked at. Rhymes for Young Ghouls combines federal boarding school and mission school as a way to signify a broad category of settler educational institutions. After this exchange, Aila's mother Anna (Roseanne Supernault) stumbles drunkenly out of the building in need of a ride home. She climbs into the front seat of her car and pulls Aila into her lap to drive. The two back out of the dirt driveway only to run over and kill the boy Tyler. In the following scene, a young Aila wakes up and her father is being taken away to jail, her mother having hung herself from the rafters. Aila will be visited by her mother-as-zombie sporadically during the film, and she dreams that her mother's corpse rises up out of the leaf-covered ground and orders her to take vengeance on the Indian Agent and schoolmaster. (Anna's husband, Joseph, says that they buried her without an Indigenous name on the marker, and that's why she still lives.) After Aila has been captured, taken to school, had her hair cut, and been placed in isolation, Tyler visits her in a dream as a zombie. Aila recalls Burner's words in the opening scene as Tyler leads Aila to a mass grave filled with Native children (Figure 4).

The drawings of other undead monsters return occasionally in the film, including in a story about a zombie wolf and its insatiable hunger for Mi'gMaq children. When Aila asks where her grandmother heard the story, the woman replies, "Before they took me off to school, my mother told it to me. Your mother is telling it to you too." Here a generational component surfaces. This is the moment that Aila decides to steal the truant tax money back from Popper, who runs the school with an iron fist and shakes down local Mi'gMaq runaways for money. The film merges Indian Agent, school superintendent, and truant officer as a way to signify a singular, bureaucratic institutional presence. But the undead presence resonates across characters as well as objects. The mysterious black car belonging to Aila's father-the one that killed young Tylerappears throughout the film as a dark presence. When Joseph returns home from prison and asks whether the car still runs, Maytag replies, "Fuck yeah. That's the weird thing-it never stopped." When Aila sees the car again in the present, she tells a young friend named Jujijj (Shako Mattawa Jacobs) who thinks the car is scary, "That's "cause it eats little kids."

Visual art figures heavily in Rhymes for Young Ghouls as redemptive and politically efficacious. It functions as a generational practice of self-representation and a way for Native women to define their oppressors. Aila has become an artist like her mother, drawing on the style of her sketches as she applies some zombie face paint for a young boy named Jujiij, who often escapes the school at night to spend time with Aila. With this disguise, he reconnoiters the school for her so she can put together a plan for the heist. Ironically, it is the strict schedule kept by Agent Popper and the other officials, educators, and priests that allows the plan to come to fruition. Aila knows exactly where each will be at every moment, and this enables her tactical counternarrative. At the climax of the film, Aila and her friends Sholo (Cody Bird), Angus (Nathan Alexis), and Maytag (Kenneth D'Ailleboust) dress up in monster costumes and raid the school. They fulfill the truant dynamic by entering the boarding school not as students but as thieves and political activists. Later, Agent Popper transforms into an even more violent bureaucrat as he attempts to recover his money and ends up dead of a gunshot wound when Jujijj saves Aila from an attempted rape. In contrast to the Agent's death, the final appearance of Aila's mother in a memory shows that she's no longer a zombie. Aila remembers 
the moment her mother taught her the political value of art-as well as the value of sometimes hiding it from those who may be watching.

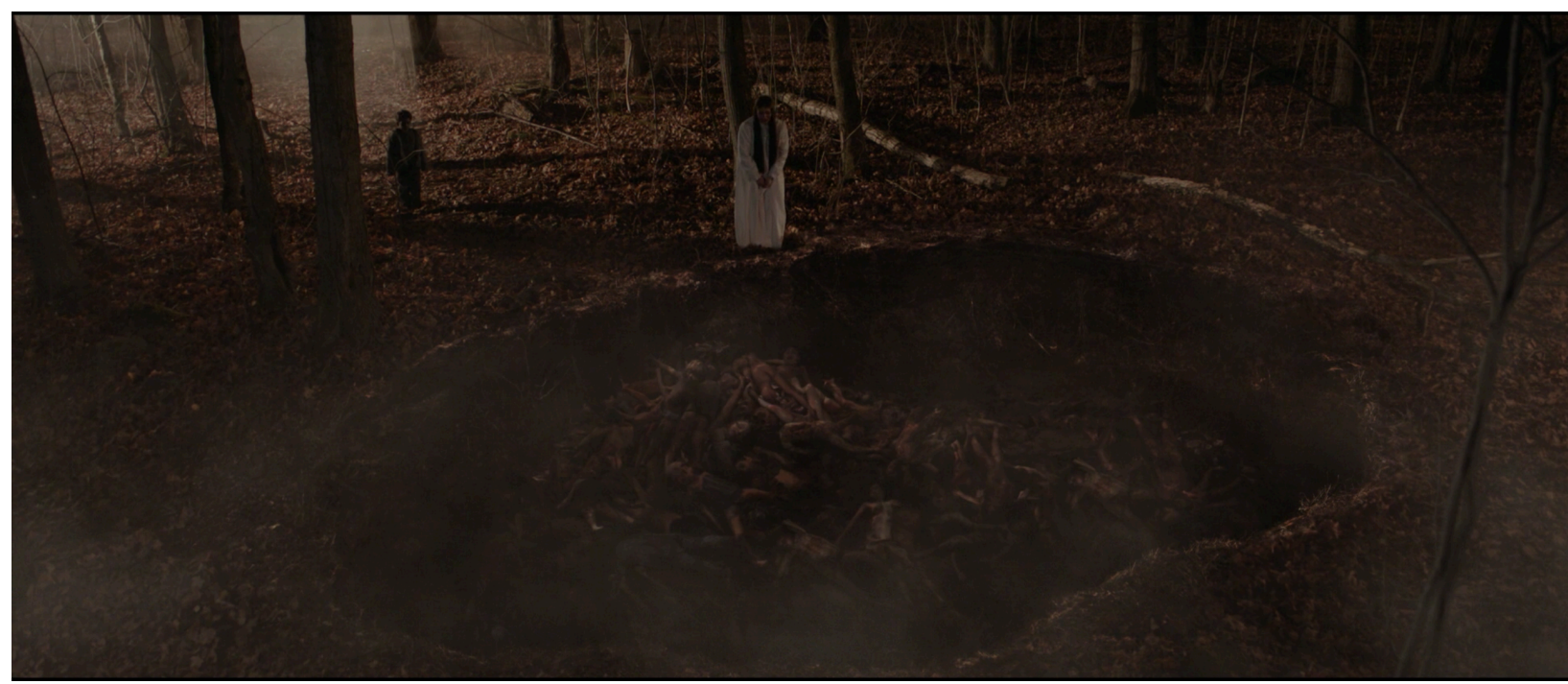

Figure 4: Aila and Tyler at a mass grave in Rhymes for Young Ghouls (Barnaby 2013).

The truant's fugitive presence generates a dynamic of sousveillance that contests totalizing administrative oversight. Whereas surveillance involves being "monitored from an external position by another entity, sousveillance is consciously employed and controlled by an individual... providing an interior, first-person perspective on their lives" (Kitchin 2014: 95). The heist that Aila and the other truants devise in Rhymes for Young Ghouls requires surveilling school officials and spaces from the perspective of Jujiij. Aila's art and Nachwihiata's literacy each articulate a truant perspective by indicting the settler-administrative officials that dog their lives. This recalls the ways that, historically, Native boarding school students expressed the same sousveillance by speaking in their Native languages about their captors and writing their own experiences of residential school, which "[counter] traditional top-down scrutiny by exerting a disciplinary effect from the bottom up" (Sewell and Barker 2006: 942-945). These expressions of escape reveal how Native children have always run from the profound ideological effects of settler education. In a contemporary cycle of Indigenous surveillance cinema, acts of undead truancy follow in this tradition.

\section{Conclusion}

These movies show how tropes of Indigenous truancy and living death capture distinct valences of movement to and from settler-bureaucratic spaces. In this regard, Indigenous surveillance cinema emphasizes the ways that administrative oversight has always produced identity rather than documented it. Early photography and cinema operated this way, borrowing from surveillance structures already present in ethnography and the widespread settler administration of Native life. Just as Vizenor (2000) associates death with ethnographic surveillance, the images of assimilation imposed on Native children elicit a kind of death that eludes surveillance. Zimmer (2015: 13) makes a similar claim: "the production of identity through surveillance narratives often betrays the ambiguity of surveillance-defined visibility, undermining the logic of both race and visual surveillance simultaneously." The "undead truant," a figure that is ambiguously there and not-there, intersects with these surveillance narratives and posits a mode of sousveillance in selfarticulation, where runaways write back at administration laterally. In this sense, Native truants escape conversion by disrupting the settler surveillance regime.

By virtue of the shared history of Indian boarding schools between US and Canada, a new generation of tribally-specific Native and First Nations media on boarding schools nevertheless expresses a broad 
Indigenous resistance to the narratives of settler education, coopting a classic colonial generalization as rhetorical strategy. These movies implement boarding school narratives (sometimes humorously, often satirically) alongside Native story traditions and contemporary filmic genres - including the western, the zombie film, and their accompanying motifs. The amalgamation reflects how Native filmmakers continue to tell their own stories as an act of narrative recalcitrance.

\section{References}

Adams, David Wallace. 1995. Education for Extinction: American Indians and the Boarding School Experience, $1875-1928$. Lawrence, KS: University Press of Kansas.

Amad, Paula. 2013. Visual Riposte: Looking Back at the Return of the Gaze as Postcolonial Theory's Gift to Film Studies. Cinema Journal 52 (3): 49-74.

Barnaby, Jeff. Rhymes for Young Ghouls. 2013. Montreal, CA: Prospector Films. DVD.

Calder, Terril. 2016. Snip. Toronto, CA: Riled Rabbits Films. DVD.

Child, Brenda J. 1998. Boarding School Seasons: American Indian Families, 1900-1940. Lincoln, NE: University of Nebraska Press.

Eils, Colleen Gleeson. 2017. Narrative Privacy: Evading Ethnographic Surveillance in Fiction by Sherman Alexie, Rigoberto Gonza'lez, and Nam Le. MELUS 42 (2): 30-52.

Fear-Segal, Jacqueline. 2006. The Man on the Bandstand at Carlisle Indian Industrial School: What He Reveals about the Children's Experiences. In Boarding School Blues: Revisiting American Indian Educational Experiences, edited by Clifford Trafzer, Jean A. Keller, and Lorene Sisquoc, 99-122. Lincoln, NE: University of Nebraska Press.

Foucault, Michel. 1995. Discipline and Punish: The Birth of the Prison. Translated by Alan Sheridan. New York: Vintage.

Hearne, Joanna. 2006. Telling and Retelling in the "Ink of Light": Documentary Cinema, Oral Narratives, and Indigenous Identities. Screen 47 (3): 307-326.

Kitchin, Rob. 2014. The Data Revolution: Big Data, Open Data, Data Infrastructures and Their Consequences. London: SAGE Publications.

Lefait, Sébastien. 2013. Surveillance on Screen: Monitoring Contemporary Films and Television Programs. Toronto: Scarecrow Press.

Levin, Thomas Y. 2002. Rhetoric of the Temporal Index: Surveillant Narration ad the Cinema of "Real Time." In CTRL[SPACE]: Rhetorics of Surveillance from Bentham to Big Brother, edited by Thomas Levin, Ursula Frohne, and Peter Weibel, 578-593. Cambridge, MA: MIT Press.

Lomawaima, K. Tsianina. 1994. They Called It Prairie Light: The Story of Chilocco Indian School. Lincoln, NE: University of Nebraska Press.

Lomawaima, K. Tsaianina, and Teresa L. McCarty. 2006. “To Remain an Indian”: Lessons in Democracy From a Century of Native American Education. New York: Teachers College Press.

Los, Maria. 2006. Looking into the Future: Surveillance, Globalization and the Totalitarian Potential. In Theorizing Surveillance: The Panopticon and Beyond, edited by David Lyon, 69-94. Devon, UK: Willan Publishing.

Lyon, David. 2007. Surveillance Studies: An Overview. Cambridge, UK: Polity Press.

Monaghan, Jeffrey. 2013. Settler Governmentality and Racializing Surveillance in Canada's North-West. The Canadian Journal of Sociology 38 (4): 487-508.

Oxford English Dictionary. N.d. Ghoul, n. Oxford, UK: Oxford University Press.

Pearson, Wendy Gay, and Susan Knabe. 2015. Reverse Shots: Indigenous Film and Media in an International Context. Waterloo, ON: Wilfrid Laurier University Press.

Perera, Suvendrini. 2015. The Craft of Killing: Trophy Bodies and Atrocity Aesthetics. Critical Arts 29 (5): $658-675$.

Pocowatchit, Roderick. 2010. The Dead Can't Dance. Witchita, KS: Rawdzilla Studios. DVD.

Raheja, Michelle H. 2013. Reservation Reelism: Redfacing, Visual Sovereignty, and Representations of Native Americans in Film. Lincoln, NE: University of Nebraska Press.

Office of Indian Affairs. 1895. Report of the Superintendent of Indian Schools to the Secretary of the Interior. Washington, DC: Government Printing Office.

Rockwell, Elsie. 2005. Indigenous Accounts of Dealing With Writing. In Language, Literacy, and Power in Schooling, edited by Teresa L. McCarty, 5-28. Mahwah, NJ: Lawrence Erlbaum Associates.

Rose, Nikolas. 1999. Powers of Freedom: Reframing Political Thought. Cambridge, UK: Cambridge University Press.

Sewell, Graham, and James R. Barker. 2006. Coercion versus Care: Using Irony to Make Sense of Organizational Surveillance. The Academy of Management Review 31 (4): 934-961.

Shohat, Ella. 2003. Post-Third-Worldist Culture: Gender, Nation, and the Cinema. In Rethinking Third Cinema, edited by Anthony R. Guneratne and Wimal Dissanayake, 51-78. New York: Routledge.

Smith, Andrea. 2014. Native Studies at the Horizon of Death: Theorizing Ethnographic Entrapment and Settler Self-Reflexivity. In Theorizing Native Studies, edited by Audra Simpson and Andrea Smith, 207-234. Durham, NC: Duke University Press Books. Stewart, Garrett. 2012. Surveillance Cinema. Film Quarterly 66 (2): 5-15.

Vizenor, Gerald. 2000. Fugitive Poses: Native American Indian Scenes of Absence and Presence. Lincoln, NE: University of Nebraska Press.

Willmott, Devin. 2009. The Only Good Indian. Lawrence, KS: TLC Films. DVD. 
Zimmer, Catherine. 2011. Surveillance Cinema: Narrative Between Technology and Politics. Surveillance \& Society 8 (4): 427440. . 2015. Surveillance Cinema. New York: New York University Press. 